\title{
Mitigasi Resiko Gadget melalui Pendampingan orang tua pada Masa Pandemi Covid-19
}

\author{
Siti Chusnul Chotimah ${ }^{\circledR}{ }^{\bowtie}$ Harun $^{1}$ \\ Pendidikan Anak Usia Dini, Universitas Negeri Yogyakarta, Indonesia(1) \\ DOI: $10.31004 /$ obsesi.v6i4.2168
}

\begin{abstract}
Abstrak
Penggunaan gadget yang berlebihan pada anak harus dihindari agar perkembangan mereka tidak terganggu. Penelitian ini bertujuan untuk menganalisis mitigasi resiko peggunaan gaget melalui pendampingan orang tua pada masa pandemic covid-19. Merupakan penelitian kualitatif deskriptif. Subjek penelitian ini adalah orang tua yang memiliki anak rentang usia 46 tahun yang ditentukan dengan teknik purposive random sampling. Data dikumpulkan dengan teknik wawancara. Data kualitatif yang dikumpulkan selanjutnya dianalisis dengan teknik triangulasi data. Hasil penelitian ini menunjukkan bahwa mitigasi resiko penggunaan gadget pada anak pada masa pendemi covid-19 dapat diupayakan melalui pendampingan orang tua. Adapun strategi yang digunakan orang tua adalah pengelolaan waktu penggunaan gadget, penggunaan aplikasi google family link, mendampingi anak saat menggunakan gadget, mengaktifkan restricted mode, pemberian sanksi dan komunikasi interpersonal. Dengan menggunakan strategi tersebut terbukti mampu mengurangi resiko dan dampak buruk penggunaan gadget pada anak. Penelitian ini diharapkan mampu mengeksplorasi mitigasi resiko gadget melalui pendampingan orang tua pada masa pandemi Covid-19 sehingga penelitian ini mampu berkontribusi terhadap penelitian selanjutnya

Kata Kunci: mitigasi resiko; Gadget ; orang tua; pandemic covid 19
\end{abstract}

\begin{abstract}
Excessive use of gadgets in children should be avoided so that their development is not disturbed. This study aims to analyze the risk mitigation of gadget use through parental assistance during the COVID-19 pandemic. This research is a descriptive qualitative research. The subjects of this study were parents of children aged 4-6 years who were determined by purposive random sampling technique. Data were collected by interview technique. The qualitative data collected was then analyzed by data triangulation techniques. The results of this study indicate that mitigating the risk of using gadgets in children during the COVID-19 pandemic can be pursued through parental assistance. The strategies used by parents are managing time using gadgets, using the Google Family Link application, accompanying children when using gadgets, activating restricted mode, giving sanctions and interpersonal communication. By using this strategy, it is proven to be able to reduce the risks and adverse effects of using gadgets on children. This research is expected to be able to explore gadget risk mitigation through parental assistance during the Covid-19 pandemic so that this research can contribute to further research
\end{abstract}

Keywords: risk mitigation; Gadgets; parent; covid 19 pandemic

Copyright (c) 2022 Siti Chusnul Chotimah

$\square$ Corresponding author :

Email Address : sitichusnul121283@gmail.com (Yogyakarta,Indonesia)

Received 26 October 2021, Accepted 15 January 2022, Published 20 January 2022

Jurnal Obsesi : Jurnal Pendidikan Anak Usia Dini, 6(4), 2022 | 2483 


\section{PENDAHULUAN}

Pendidikan Anak Usia Dini merupakan pondasi dasar bagi penanaman pengetahuan bagi anak karena pada usia ini merupakan masa keemasan sehingga perkembangan anak akan maksimal apabila dilakukan sesuai dengan tahapan perkembangan dan karakteristik anak.pendidikan anak usia dini sangat penting diantaranya membantu mengembangkan seluruh potensi dan kecerdasan anak yang sesuai dengan tahapan perkembangan anak agar siap memasuki pendidikan selanjutnya (D. Roza et al., 2019).

Pada saat ini Pandemi covid-19 yang telah terjadi di seluruh belahan dunia membawa dampak yang cukup serius, salah satunya bagi Indonesia (Putri, 2021). Dampak dari pandemi ini secara umum telah menghambat laju pertumbuhan dan kemajuan dari berbagai bidang kehidupan. Dampak yang paling dirasakan adalah di bidang perekonomian yang merupakan hal yang paling menyentuh sisi kehidupan manusia. Demikian pula dari aspek pendidikan mengalami dampak yang sangat signifikan oleh karena pandemi ini.(Karnawati \& Mardiharto, 2020). Sebagai upaya mengantisipasi penyebaran Covid-19, Kemendikbud menerbitkan surat Surat Edaran Nomor 15 Tahun 2020 tentang bagaimana pedoman dalam menyelenggarakan proses belajar secara daring dimasa darurat Covid-19. Dalam pedoman surat edaran tersebut dijelaskan bahwa tujuan yang ingin dilakukan dalam menjalankan Proses Belajar Dari Rumah (BDR) yaitu dapat memenuhi hak dari anak didik berupa pelayanan pendidikan yang tetap berjalan selama masa tanggap darurat tersebut, melindungi dari dampak buruk terhadap warga satuan pendidikan, memutus mata rantai penyebaran dan penularan dalam satuan pendidikan dan memberikan dukungan penuh dampak psikososial terhadap para guru, anak didik, dan para orang tua, serta merekomendasikan sebanyak 23 laman yang dapat diakses oleh orangtua dan guru sebagai sumber belajar anak didik dirumah selama masa darurat covid-19 (Kemendikbud, 2020).

Kebijakan Belajar Dari Rumah (BDR) ditujukan kepada semua jenjang pendidikan, mulai dari Taman Kanak-kanak (TK) hingga perguruan tinggi. Kegiatan BDR dilakukan guna memutus rantai Covid-19 dalam bidang pendidikan. Sehubungan dengan kegiatan BDR, guru tetap memantau kegiatan yang dilakukan oleh siswa.Kegiatan BDR dilakukan dengan memanfaatkan kemajuan teknologi masa kini, yaitu Gadget (Astuti \& Harun, 2020).

Dalam bahasa Indonesia, gadget disebut sebagai "gawai". Istilah gadget sebagai benda dengan karakteristik unik, memiliki sebuah unit dengan kinerja yang tinggi dan berhubungan dengan ukuran serta biaya. Menurut Derry Iswidharmanjaya gadget adalah perangkat atau instrument elektronik yang memiliki tujuan dan fungsi yang praktis terutama untuk membantu pekerjaan manusia.(Novitasari, 2019). Gadget dalam pengertian umum dianggap sebagai suatu perangkat elektronik yang memiliki fungsi khusus pada setiap perangkatnya. Contohnya: komputer, handphone, game dan lainnya.(Chusna, 2017).

Sedangkan fungsi gadget dapat diterjemahkan menjadi 3 poin. Pertama, sebagai alat komunikasi, menggunakan gadget berupa smartphone di era milenial ini akan lebih nyaman, cepat, praktis, dan efisien dalam berkomunikasi. Fungsi kedua, sebagai jejaring sosial, penggunaan aplikasi media sosial, dapat dengan mudah berbagi berita, cerita, dan bahkan menjalin hubungan dengan kerabat, teman, dan kerabat jauh. Sedangkan fungsi ketiga adalah fungsi pendidikan. Gadget dengan mudah mengakses berbagai ilmu pengetahuan, ilmu politik, diskusi, menyebarkan dakwah dengan cepat dan mudah tanpa harus pergi ke perpustakaan. [6] Selain itu, ada fungsi hiburan di mana aplikasi Gadget dapat menjadi pemutar musik dan game baik online maupun online (Muyasaroh et al., 2020)

Secara umum, menurut Sahriana (2019), penggunaan gadget memberikan dampak positif sebagai berikut: (1) memperluas wawasan dan jaringan pertemanan, (2) memudahkan proses komunikasi dengan teman, dan (3) melatih kreativitas anak. Selain itu, penggunaan gadget juga memberikan dampak negative, diantaranya: (1) mengganggu kesehatan, (2) mengganggu perkembangan anak, (3) rawan terhadap tindak kejahatan, dan (4) mempengaruhi perilaku anak. Dengan mempertimbangkan dampak negative dari gadget, 
maka peran orang tua sangatlah penting. Ada beberapa cara yang dapat dilakukan orang tua, antara lain: (1) memilihkan fitur pada gadget yang relevan dengan usia anak; (2) mendampingi anak selama penggunaan gadget; (3) memberi batasan waktu anak untuk menggunakan gadget; (4) menghindari kecanduan gadget pada anak dengan memberikan aturan; dan (5) membantu anak dalam penyesuaian diri dengan lingkungan dan perkembangan zaman (Asmawati, 2021).

Gadget memiliki pengaruh besar terhadap kehidupan manusia. Seperti halnya Gadget memberikan dampak yang begitu besar pada anak-anak di masa pandemi ini. Sehingga penggunaan alat komunikasi semakain meningkat di era pandemi Covid 19 (Najwa, 2021). Proses BDR membuat anak lebih sering berinteraksi dengan gadget karena pembelajaran dilakukan secara daring (Maria \& Novianti, 2020). Pendampingan orang tua terhadap penggunaan gadget semakin penting di saat pandemi Covid-19 menyerang kehidupan masyarakat seperti saat ini (Sisbintari \& Setiawati, 2021). Orang tua berperan penting dalam mencegah terjadinya adiksi gadget pada anak (Nurhidayah et al., 2019). Salah satu upaya orang tua dalam memberikan pendidikan bagi anak dalam keluarga di era digital seperti sekarang adalah dengan memberikan pendampingan dalam penggunaan teknologi bagi anak. Melalui pendampingan tersebut, orang tua dapat mengawasi anak dan mengarahkan kontenkonten positif bagi anak untuk menggunakan kemajuan teknologi secara tepat sesuai dengan masa tumbuh kembang anak (Alia \& Irwansyah, 2018).

Adapun pendampingan yang dikemukakan oleh Wasrisyah, (2015) adalah dengan cara orang tua mendampingi anaknya yang sedang menggunakan gadget, mengarahkan anak untuk membuka hal-hal yang sesuai dengan tahap perkembangannya. Pendampingan yang dimaksud yaitu orang tua tidak hanya melihat anaknya ketika bermain gadget, tetapi orang tua juga mampu menjadi guru bagi anaknya. Orang tua juga harus memberi batasan waktu untuk anak dalam menggunakan gadget, misalnya sehari anak hanya diperbolehkan bermain gadget selama satu jam dengan fitur-fitur yang mendukung perkembanganya (Nurhidayah et al., 2019).

Selain pendampingan, orang tua juga diharapkan dapat menjalankan perannya untuk mendidik anak dalam penggunaan gadget seperti memberikan pengertian dan edukasi mengenai cara penggunaan gadget yang baik serta memberitahu tentang dampak baik dan dampak buruk (Christina et al., 2020).

Orang tua harus memiliki kontrol penuh dan ikut mengawasi semua arus informasi yang diterima anak serta memberi penjelasan yang baik dan tepat mengenai itu semua (Prasanti, 2016). Orang tua sebaiknya mengawasi anak dalam menggunakan gadget sehingga tidak mengganggu proses sosialisasi terhadap lingkungan. Orang tua perlu memberikan beberapa aturan kepada anak tentang penggunaan gadget agar dapat bermanfaat secara maksimal (Mubashiroh, 2013). Bentuk pengawasan orang tua pada anak ketika menggunakan smartphone yaitu dengan memberikan pembatasan waktu dalam menggunakan smartphone, memberikan nasihat kepada anak supaya menggunakan smartphone dengan semestinya, memberikan sanksi kepada anak yang tidak mematuhi aturan yang telah dibuat orang tuanya (F. Utama \& Hasti Hasmira, 2019).

Pendampingan orang tua kepada anak juga harus terjadi melalui komunikasi, yaitu komunikasi interpersonal. Dari kelima elemen komunikasi interpersonal yaitu keterbukaan, empati, dukungan, rasa positif, dan kesetaraan atau kesamaan (Tasya \& Masitoh, 2020). Orang tua bisa berkomunikasi dengan anak melalui komunikasi antarpribadi, orang tua dapat memberitahukan apa saja dampak negatif yang terjadi apabila anak terus menerus bermain gadget (Olifia \& Nuraini, 2018).

Beberapa penelitian telah mengkaji tentang peran orang tua dalam mendampingi anak selama pandemic covid-19. Anita Wardani (Wardani \& Ayriza, 2020) mengungkapkan bahwa secara umum kendala- kendala orang tua dalam mendampingi anak belajar di rumah pada masa pandemi Covid- 19 adalah kurangnya pemahaman materi oleh orang tua, kesulitan orang tua dalam menumbuhkan minat belajar anak, tidak memiliki cukup waktu untuk mendampingi anak 
karena harus bekerja, orang tua tidak sabar dalam mendampingi anak saat belajar dirumah, kesulitan orang tua dalam mengoperasikan gadget, dan kendala terkait jangkauan layanan internet. Selfi Lailiyatul Iftitah dan Mardiyana Faridhatul Anawaty (Iftitah \& Anawaty, 2020) mengungkapkan bahwa peran penting orang tua dalam mendampingi anak yaitu Anak merasa tidak sendiri, orang tua sebagai pemberi semangat, memfasilitasi kebutuhan anak, tempat berdiskusi dan bertanya, membantu mengenali diri sendiri, melihat dan mengembangkan bakat anak dan menciptakan lingkungan yang kondusif untuk belajar. Nurjanah, Yully Setyorini, Cintya Nurika Irma (Nurjanah \& Irma, 2020) mengungkapkan bahwa Motivasi yang diberikan oleh orang tua kepada anak mampu menjadikan anak lebih semangat dalam belajar orang tua menjadi memiliki banyak waktu untuk membimbing dan mendampingi anak belajar daring, serta hubungan antara anak dan orang tua menjadi terjalin lebih erat dibandingkan sebelumnya.

Dari beberapa penelitian yang diuraikan tersebut, belum ada penelitian yang mengarah pada upaya mitigasi resiko gadget melalui pendampingan orang tua pada masa pandemic covid-19. Penelitian ini mengambil posisi untuk mengkaji secara mendalam tentang upaya orang tua dalam mengurangi dampak penggunaan gadget selama pandemi Covid-19. Hadirnya penelitian ini akan memberikan dan menambah referensi untuk orang tua tentang upaya mengurangi dampak penggunaan gadget selama pandemi Covid-19 ini.

\section{METODOLOGI}

Penelitian ini menggunakan pendekatan kualitatif. Jenis penelitian yang digunakan adalah penelitian kualitatif deskriptif. Penelitian ini bertujuan untuk mendeskripsikan upaya mitigasi resiko gadget melalui pendampingan orang tua Gambar 1 disajikan desain penelitian yang digunakan pada penelitian ini

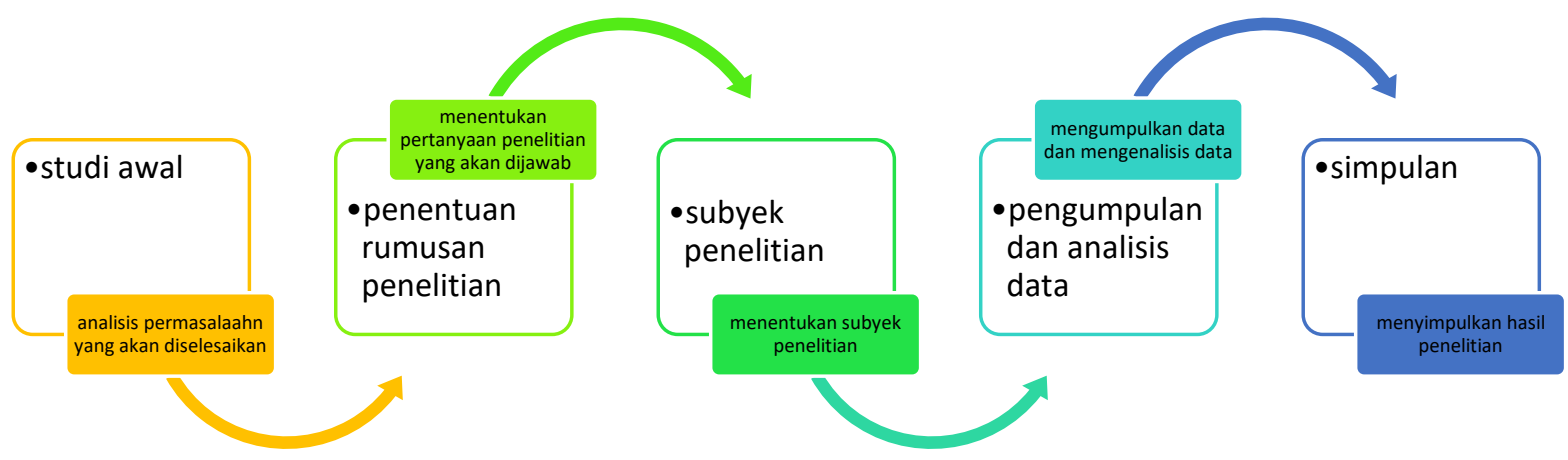

\section{Gambar 1. Desain Penelitian}

Penelitian ini dilaksanakan di TK ABA Bero III, Kecamatan Trucuk, Kabupaten Klaten, Provinsi Jawa Tengah Daerah, Indonesia. Subjek penelitian ini adalah orang tua siswa TK. Orang tua yang dilibatkan pada penelitian ini berjumlah 15 orang. Penentuan subjek penelitian ini dilakukan dengan menggunakan teknik purposive random sampling. Subjek penelitian yang dilibatkan pada penelitian ini harus memenuhi beberapa kriteria yaitu 1) memiliki anak rentang usia 4-6 tahun; 2) anaknya harus merupakan siswa TK; dan 3) anaknya sudah bisa menggunakan gadget. Penentuan kriteria tersebut adalah untuk memenuhi kebutuhan data penelitian dikarenakan penelitian ini membutuhkan informasi atau data dari para orang tua siswa TK yang telah menjalankan pembelajaran Daring. Subjek penelitian ini dapat dilihat pada data yang disajikan pada tabel 1. Penelitian ini dilaksanakan pada bulan Januari tahun 2022 di TK ABA Bero III, Kecamatan Trucuk, Kabupaten Klaten. Pelaksanaan penelitian ini melewati beberapa prosedur, diantaranya: (1) Melakukan studi pendahuluan untuk menemukan masalah yang akan diteliti; (2) Menentukan subjek atau informan 
penelitian yang sesuai yaitu orang tua siswa TK yang dipilih dengan teknik purposive random sampling menggunakan beberapa kriteria khusus; (3) Melakukan wawancara tentang upaya

mitigasi resiko gadget melalui pendampingan orang tua digunakan orang tua untuk mengurangi dampak penggunaan gadget; (4) Mengelompokkan data yang diperoleh; (5) Melakukan analisis data hasil wawancara yang diperoleh; (6) Menarik kesimpulan penelitian.

Tabel 1. Subjek Penelitian

\begin{tabular}{|c|c|c|c|c|}
\hline NAME & GENDER & AGE & CHILD'S AGE & INFORMATION \\
\hline $\mathrm{T}$ & female & 42 years old & 4 years old & subject 1 \\
\hline TL & female & 31 years old & 6 years old & subject 2 \\
\hline NS & female & 31 years old & 5 years old & subject 3 \\
\hline SR & female & 31 years old & 6 years old & subject 4 \\
\hline SM & female & 42 years old & 5 years old & subject 5 \\
\hline PY & female & 35 years old & 5 years old & subject 6 \\
\hline WN & female & 26 years old & 4 years old & subject 7 \\
\hline w & female & 34 years old & 5 years old & subject 8 \\
\hline SM & female & 38 years old & 6 years old & subject 9 \\
\hline SS & female & 41 years old & 5 years old & subject 10 \\
\hline $\mathrm{S}$ & female & 42 years old & 5 years old & subject 11 \\
\hline $\mathrm{TE}$ & female & 28 years old & 4 years old & subject 12 \\
\hline $\mathrm{T}$ & female & 36 years old & 5 years old & subject 13 \\
\hline DWS & female & 39 years old & 5 years old & subject 14 \\
\hline$F R$ & female & 36 years old & 6 years old & subject 15 \\
\hline
\end{tabular}

Tenik pengumpulan data yang digunakan pada penelitian ini adalah wawancara. Teknik wawancara digunakan untuk memperoleh informasi-informasi tentang upaya mitigasi resiko gadget melalui pendampingan orang tua pada anak selama pandemi Covid-19 ini. Jenis wawancara yang digunakan adalah wawancara terstruktur dengan menentukan aspek dan indikator yang akan digali secara mendalam. Data hasil wawancara dari informan-informan penelitian dijadikan sebagai data utama penelitian yang akan dianalisis lebih lanjut sebelum menyimpulkan hasil penelitian. Data yang diperoleh merupakan data kualitatif yang dianalisis dengan teknik triangulasi data. Tabel kisi-kisi instrumen wawancara pada penelitian ini dapat dilihat pada data tabel 2.

\section{Tabel 2. Kisi-Kisi Instrumen Wawancara}

\begin{tabular}{|c|c|}
\hline Aspek & $\begin{array}{r}\text { Indikator } \\
\end{array}$ \\
\hline \multirow[t]{3}{*}{ Pendampingan } & 1. Membatasi waktu dalam penggunaan gadget \\
\hline & 2. Mengarahkan anak dalam memilih konten yang positif \\
\hline & 3. Mendampingi anak saat menggunakan gadget \\
\hline \multirow[t]{2}{*}{ Pendidikan } & 1. Memberi pengertian cara penggunaan gadget \\
\hline & 2. Mengedukasi dampak baik dan buruk penggunaan gadget \\
\hline \multirow[t]{3}{*}{ Pengawasan } & 1. Mengawasi segala bentuk informasi yang diperoleh \\
\hline & 2. Memberi sanksi penyalahgunaan gadget \\
\hline & 3. Memantau riwayat penggunaan gadget. \\
\hline \multirow[t]{2}{*}{ Komunikasi } & 1. Mengkomunikasikan hal-hal yang tidak diketahui anak secara terbuka \\
\hline & 2. Mengkomunikasikan kesepakatan aturan penggunaan gadget \\
\hline
\end{tabular}


Teknik analisis data yang digunakan pada penelitian ini adalah teknik triangulasi data dengan membandingkan data-data yang diperoleh. Analisis data pada penelitian ini sendiri melalui beberapa tahap yaitu (1) Mengumpulkan data wawancara tentang mitigasi resiko penggunaan gadget yang diterapkan oleh orang tua kepada anak usia dini selama masa pandemi Covid-19; (2) Menyajikan data yang diperoleh dari semua informan dalam bentuk tabel deskripsi; (3) Menganalisis dan mereduksi data-data dengan cara membandingkan data yang diperoleh untuk menemukan upaya atau tindakan untuk mengurangi resiko penggunaan gadget yang digunakan orang tua kepada anak usia dini selama pandemi Covid19; (4) Mengecek kembali dan melakukan sinkronisasi data untuk menemukan suatu data yang valid dan absah; dan (5) Menarik suatu kesimpulan penelitian. Proses triangulasi terus dilakukan hingga hasilnya Mitigasi Resiko Gadget Melalui Pendampingan orang tua Pada Masa Pandemi Covid-19 dapat dijadikan referensi yang memiliki konsistensi untuk menjawab pertanyaan penelitian. Apabila data masih belum konsisten dan penarikan kesimpulan belum bisa dilaksanakan, maka proses triangulasi akan terus dilakukan secara berulang hingga data yang diperoleh konsisten

\section{HASIL DAN PEMBAHASAN \\ Pengelolaan waktu penggunaan gadget}

Pengelolaan waktu merupakan bagian dari bentuk pendampingan orang tua untuk mengurangi resiko atau pembatasan penggunaan gadget bagi anak. Orang tua memiliki berbagai cara dalam pengelolaan waktu untuk mengurangi resiko atau dampak buruk penggunaan gadget. Sebagian orang tua menerapkan pembuatan jadwal penggunaan gadget bagi anak mereka. Jatah waktu yang diberikan sesuai dengan kesepakatan yang telah dibuat bersama antara orang tua dan anak.

"Kalau saya memberikan jatah waktu anak manggunakan gadget sesuai dengan situasi. Misalnya pada waktu hari belajar efektif saya memberi jatah waktu dua jam, diluar penggunaan gadget untuk pembelajaran daring. Namun saat hari libur saya memberi jatah waktu lebih banyak sekitar 3-4 jam dalam sehari" (Interview 1. DWS. 4 Januari 2022)

Selain itu ada juga orang tua yang mengatur waktu penggunaan gadget berdasarkan pemilihan waktu. Sebagai contoh ada yang menerapkan aturan penggunaan gadget setelah anak pulang dari sekolah, ada pula yang memberikan waktu sesudah anak tidur siang, dan ada juga yang memilih waktu sesudah anak makan malam. Setiap orang tua memiliki alasan masing-masing terhadap pemilihan waktu yang mereka pilih.

"Saya mengijinkan anak saya menggunakan gadget setelah anak saya tidur siang, karena menurut saya setelah bangun tidur siang anak sudah tidak merasa lelah lagi setelah melaksanakan kegiatan pembelajaran dari pagi. Jadi ada jeda waktu penggunaan gadget untuk pembelajaran daring dan penggunaan gadget untuk sekedar bermain" (Interview 2. SM. 4 Januari 2022)

Berdasarkan data yang diperoleh dari informan menunjukkan bahwa pendampingan orang tua melalui pengelolaan waktu dapat diterapkan dan dijalankan dengan baik. Selain itu cara ini mampu mengalihkan perhatian anak dari gadget dan memilih untuk melakukan aktivitas atau permainan lain yang lebih bermanfaat bagi perkembangan anak. Berdasarkan dari uraian data tersebut, maka dapat disimpulkan bahwa penerapan pengelolaan waktu penggunaan gadget dapat digunakan sebagai salah satu cara mengurangi resiko atau dampak buruk penggunaan gadget pada anak.

Sosok yang paling berpengaruh dalam mencegah maupun mengatasi dampak negatif dari gadget adalah orang tua. Maka orang tua memiliki peran besar dalam membimbing dan 
mencegah agar teknologi gadget tidak berdampak negatif bagi anak (Novitasari, 2019). Pengawasan orang tua terhadap pendidikan anak di rumah selama pandemi sangat penting, untuk mencegah anak mengalami kebosanan, stress dan lain sebagainya saat menerima tugastugas yang banyak dari guru di sekolah (Lase \& Tafonao, 2021). Berbagai cara yang dilakukan oleh para orang tua untuk mengurangi resiko dan dampak negative penggunaan gadget pada anak bervariasi. Salah satu cara yang digunakan adalah dengan membuat perjanjian dengan anak tentang jadwal penggunaan gadget. Penjadwalan ini menjadi sangat penting agar penggunaan gadget pada anak tidak terlalu intens (Sisbintari \& Setiawati, 2021). Pembatasan waktu dalam penggunaan smartphone oleh anak merupakan salah pengawasan yang dilakukan oleh orang tua, dimana si anak menggunakan smartphone hanya pada waktuwaktu tertentu saja (F. Utama \& Hasti Hasmira, 2019).

\section{Penggunaan aplikasi google family link}

Pengawasan penggunaan gadget dapat dilakukan dengan bantuan aplikasi yang bisa digunakan untuk mengontrol pemakaian smartphone android yaitu aplikasi Google Family Link. Melalui Google Family Link, orang tua dapat membuat aturan tentang apa saja yang bisa di akses anak-anak.

"Saya tidak memiliki cukup waktu untuk selalu mendampingi anak saya dalam menggunakan gadget karena saya harus bekerja. Jadi saya memilih untuk menggunakan aplikasi google family link untuk membatasi anak dalam menggunakan gadget. Dengan menggunakan aplikasi tersebut sangat membantu saya dalam mengontrol dan mengawasi anak saya dalam menggunakan gadget walaupun saya tidak berada di samping anak saya" (Interview 3. TL. 5 Januari 2022)

Berdasarkan dari paparan informasi tersebut dapat disimpulkan bahwa para orang tua melakukan pengawasan kepada anaknya saat menggunakan gadget dengan cara menggunakan aplikasi google family link. Google Family Link merupakan aplikasi seluler yang memungkinkan untuk membatasi jumlah waktu anak-anak menggunakan smartphone, memantau aktivitas internet mereka dan menjaga keamanan dari situs yang tidak pantas. Aplikasi ini dirancang untuk anak-anak usia 13 tahun ke bawah, menggunakan kontrol orang tua. Google Family Link melibatkan pengaturan akun Google pribadi untuk anak yang dapat dipantau dan dikontrol (F. P. Utama et al., 2021).

Pada langkah awal, akun Gmail orang tua akan ditetapkan sebagai family manager , dengan proses berikutnya yang melibatkan kode pemasangan yang dihasilkan secara acak dari aplikasi Family Link For Parents. Kemudian orang tua memasukkan kode pemasangan di aplikasi Family Link For Children \& Teens. Setelah proses pemasangan selesai, sebagai orang tua bisa melakukan moderasi konten internet di smartphone Android yang digunakan anak. Beberapa fitur utama Family Link antara lain adalah memantau aplikasi yang digunakan dan durasi total penggunaannya, memantau unduhan aplikasi di PlayStore, menentukan batas waktu penggunaan smartphone, memantau lokasi anak dari sensor GPS. Melalui aplikasi Google Family Link, orang tua memegang kekuasaan penuh atas gadget yang dimiliki anak karena gadget orang tua dan anak saling terhubung dan tidak dapat diputus sepihak (Faozi et al., n.d.). Adapun cara penggunaan google family link dapat dilihat pada gambar 1. 


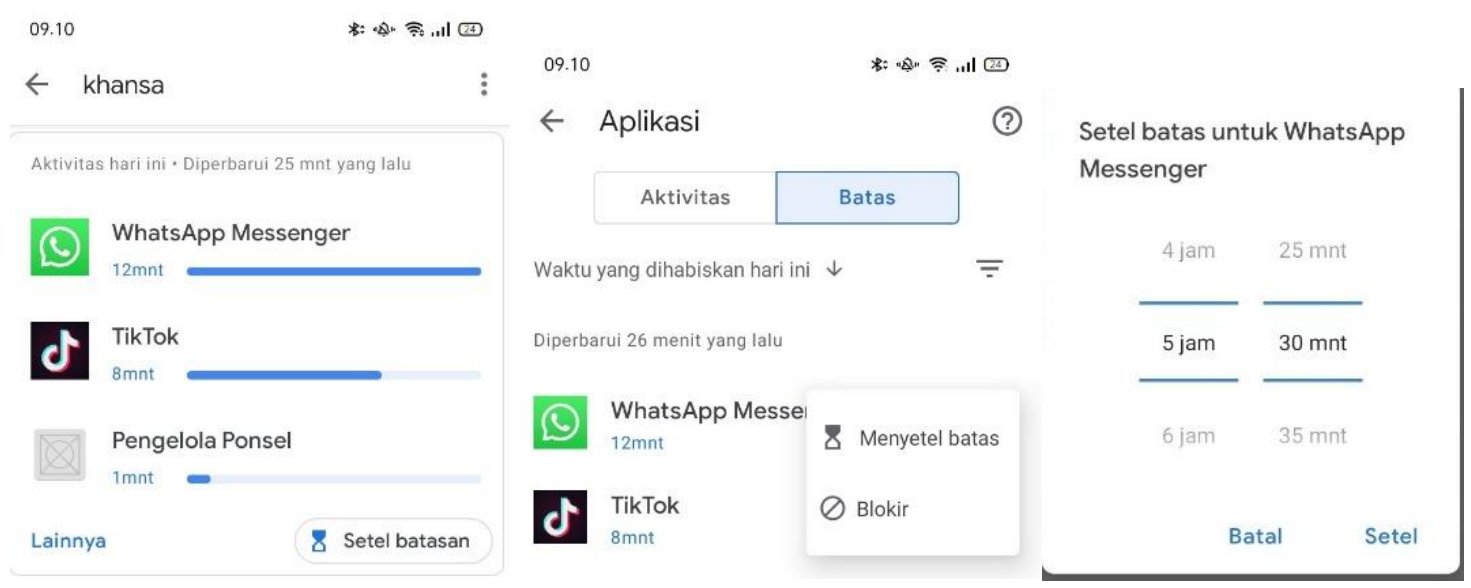

Gambar 1. Cara penggunaan google family link

\title{
Mendampingi anak saat menggunakan gadget
}

Mendampingi anak saat menggunakan gadget merupakan salah satu upaya mengurangi resiko atau dampak buruk penggunaan gadget pada anak. Beragam pendampingan yang dilakukan orang tua diantaranya dengan berada di samping anak saat anak meggunakan gadget, mengarahkan anak dalam memilih konten, kemudian mengajari anak cara menggunakan gadget dengan baik, serta membatasi aplikasi yang boleh dan tidak boleh diakses oleh anak.

\begin{abstract}
"Saya meluangkan waktu untuk menemani anak saya menggunakan gadget agar saya dapat memantau aplikasi apa yang sedang dibuka oleh anak saya, selain itu saya selalu mengingatkan untuk tidak membuka situs atau website yang tidak sesuai dengan usia anak. Di samping itu saya selalu membantu anak saya memegang ponsel dengan tujuan agar dapat mengontrol jarak ponsel dengan mata agar dapat menjaga kesehatan matanya. Terkadang saya harus mengalihkan perhatian anak dengan permainan keluar rumah agar anak mau meletakkan gadgetnya" (Interview 4. TE. 5 Januari 2022)
\end{abstract}

Data yang diperoleh dari informan juga menunjukkan bahwa mendampingi anak saat menggunakan gadget mampu mengurangi dampak buruk penggunaan gadget. Dengan cara tersebut berhasil membuat perhatian anak mereka teralihkan dari gadget dan cenderung ke aktivitas bermain yang lebih produktif. Dengan berada disamping anak orang tua dapat mengetahui informasi atau konten apa yang sedang dibuaka anak. Apabila anak sedang menggunakan gadget orang tua harus mendampingi anaknya, mengarahkan untuk membuka fitur-fitur yang sesuai dengan tahap perkembanganya (Warisyah, 2015). Hendaknya orang tua tidak membiarkan anak bermain internet sendiri di dalam kamar, agar tertutup peluang bagi anak membuka situs-situs yang dilarang (Saefulloh, 2018).

\section{Mengaktifkan restricted mode}

Pengawasan penggunaan gadget merupakan upaya mitigasi resiko penggunaan gadget pada anak. Namun, tidak semua orang tua memiliki banyak waktu luang untuk mengawasi anak. Salah satu cara pengawasan tanpa sepengetahuan anak adalah dengan mengaktifkan restricted mode. Restricted mode merupakan fitur pada aplikasi you tube yang dapat menyembunyikan video dengan konten yang dianggap tidak pantas, yang pernah ditandai oleh pengguna atau dengan pelaporan yang lain. Mode ini membuat You tube juga Google secara otomatis mendeteksi dan memblokir akses dari konten yang tidak pantas dan tidak sesuai (dengan batasan) usianya. 
DOI: $10.31004 /$ obsesi.v6i3.2168

"Saya mengaktifkan restricted mode karena aplikasi yang sering dibuka oleh anak saya adalah aplikasi you tube, dimana tidak semua konten sesuai dengan usia anak. Dengan mengaktifkan restricted mode saya merasa aman dan nyaman karena secara otomatis dapat menyaring konten yang tidak pantas untuk anak." (Interview 5. PY. 5 Januari 2022)

Berdasar pada uraian data yang disajikan, dapat disimpulkan bahwa penggunaan fitur restricted mode dapat membantu orang tua mengawasi penggunaan gadget terutama dalam hal pemilihan konten yang sesuai dengan usia anak. Langkah awal orang tua dapat membuat "Restricted Mode/mode tebatas" dimana pada fitur tersebut ketika orang tua menginginkan kontrol hal-hal berbau porno dan berbahaya pada YouTube. Caranya, buka aplikasi YouTube pada halaman bagian yang paling bawah selanjutnya klik [Restricted Mode: Off] dan selanjutnya akan ada pilihan dalam mengaktikan ON-OFF (Yannuansa et al., 2020). Dengan mensetting aplikasi google pada aplikasi-aplikasi maka system akan memblok gambar, video, dan situs yang eksplisit dari hasil pencarian pada google. Selain itu dengan tool yang diberikan maka pengguna aplikasi google bisa melaporkan situs yang mengandung konten-konten yang tidak pantas (E. Roza et al., 2018). Adapun cara mengaktifkan restricted mode dapat dilihat pada gambar 2 .

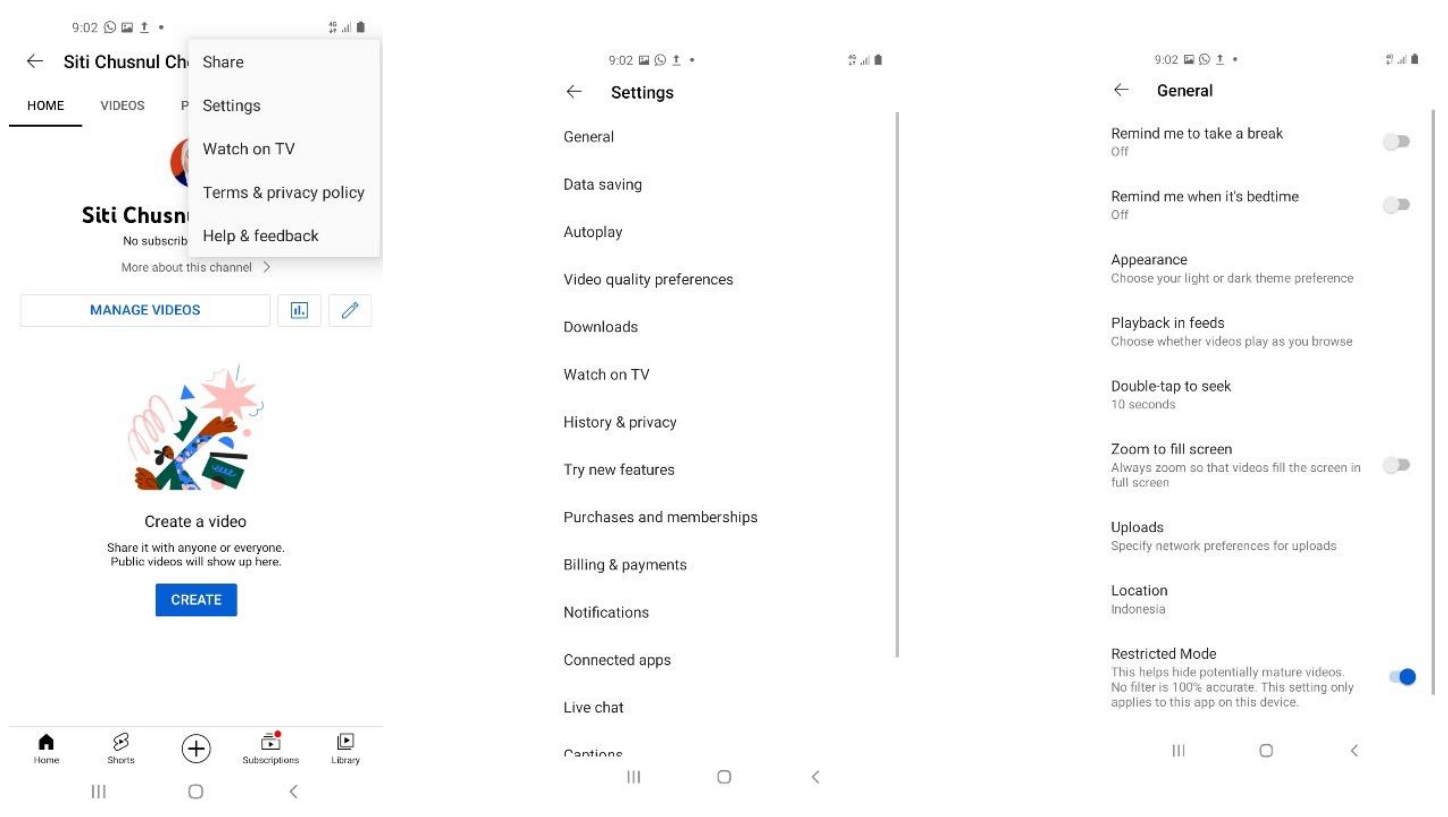

Gambar 2. Cara mengaktifkan restricted mode

\section{Pemberian sanksi}

Upaya selanjutnya adalah dengan pemberian sanksi kepada anak apabila anak melakukan perbuatan yang tidak sesuai kesepakatan yang telah dibuat antara orang tua dan anak dalam menggunakan gadget. Hal ini dilakukan untuk melatih kedisiplinan dan menumbuhkan rasa tanggung jawab kepada anak atas perbuatannya.

"saya tidak segan memberikan hukuman kepada anak saya saat dia bermain game melebihi waktu yang telah ditentukan, hukuman yang saya berikan adalah dengan mengurangi jatah waktu pemakaian gadget di hari berikutnya dan uang jajannya saya kurangi" (Interview 6. SS. 6 Januari 2022)

Berdasarkan data yang diperoleh dari informan hukuman yang diberikan kepada anak mampu menimbulkan efek jera kepada anak, sehingga anak kembali mentaati kesepakatan awal yang telah dibuat bersama dengan orang tua. Sanksi merupakan langkah hukuman yang dilakukan oleh orang tua kepada anaknya apabila anak tidak mematuhi aturan yang telah dibuat oleh orang tuanya sendiri. Sanksi tersebut memberikan efek jera kepada anaknya agar 
menggunakan smartphone sesuai dengan ketentuan yang berlaku. Sanksi yang diberikan oleh orang tua pun ada sanksi berupa sanksi fisik dan non fisik (F. Utama \& Hasti Hasmira, 2019).

\section{Komunikasi interpersonal}

Komunikasi yang baik antara orang tua dan anak mampu membangun kesadaran pada anak untuk mematuhi peraturan yang telah ditetapkan orang tua. Komunikasi yang buruk mengakibatkan kesalah pahaman pada anak, sehingga anak menjadi membangkang dan tidak mematuhi aturan orang tua.

"Dalam pemilihan konten atau aplikasi yang bisa diakses anak terlebih dahulu saya komunikasikan secara terbuka kepada anak saya kemudian saya jelaskan kepada anak kenapa konten ini boleh atau tidak boleh diakses. Dalam berkomunikasi saya memposisikan diri saya sebagai teman dan menggunakan bahasa yang dimengerti oleh anak saya". (Interview 7. FR. 6 Januari 2022)

pendampingan orang tua kepada anak juga harus terjadi melalui komunikasi, yaitu komunikasi interpersonal. Dari kelima elemen komunikasi interpersonal yaitu keterbukaan, empati, dukungan, rasa positif, dan kesetaraan atau kesamaan, keenam informan cenderung mengawali hubungan interpersonal dengan anaknya melalui tahap keterbukaan terlebih dahulu. Kemudian, memberikan pendampingan berupa waktu dan komunikasi interpersonal yang terjadi secara langsung dan rutin, akan membuat anak terbiasa, terlatih dan dapat membangun sikap dan pola pikir yang baik dari anak-anak tersebut (Tasya \& Masitoh, 2020).

Komunikasi interpersonal dalam keluarga yang dilakukan antara orang tua dengan anak merupakan salah satu faktor penting dalam menentukan perkembangan anak. Komunikasi yang diharapkan adalah komunikasi yang efektif, karena dapat memunculkan rasa pengertian, kesenangan, pengaruh pada sikap, dan hubungan yang semakin baik. Sehingga dengan dilakukannya komunikasi yang efektif yang terjalin antara orangtua dengan anak akan timbulnya hubungan harmonisasi sehingga anak akan senantiasa mendengarkan dan mengikuti perintah orangtuanya termasuk dalam hal penggunaan gadget (Nurhidayah et al., 2019).

\section{SIMPULAN}

Mitigasi resiko penggunaan gadget pada anak pada masa pendemi covid-19 dapat diupayakan melalui pendampingan orang tua. Adapun strategi yang digunakan orang tua adalah 1) pengelolaan waktu penggunaan gadget; 2) penggunaan aplikasi google family link; 3) mendampingi anak saat menggunakan gadget; 4) mengaktifkan restricted mode; 5) pemberian sanksi; 6)komunikasi interpersonal. Penelitian ini baru pada tahap mendalami strategi-strategi yang dilakukan oleh para orang tua saja, masih dibutuhkan penelitian lebih lanjut untuk memperkuat hasil penelitian ini berupa penelitian yang menguji masing-masing startegi tersebut.

\section{UCAPAN TERIMA KASIH}

Kami mengucapkan terima kasih kepada pihak-pihak yang sudah membantu dalam menyelesaikan artikel jurnal ini, semoga Allah SWT membalas dengah balasan yang paling baik. Aamiin

\section{DAFTAR PUSTAKA}

Alia, T., \& Irwansyah. (2018). Pendampingan orang tua pada anak usia dini dalam penggunaan teknologi digital. A Journal of Language, Literature, Culture and Education, 14(1), 65-78. https:// doi.org/10.19166/pji.v14i1.639 
Asmawati, L. (2021). Peran Orang Tua dalam pemanfaatan teknologi digital pada anak usia dini. Jurnal Obsesi: Jurnal Pendidikan Anak Usia Dini, 6(1), 82-96. https://doi.org/10.31004/obsesi.v6i1.1170

Astuti, I. Y., \& Harun, H. (2020). Tantangan Guru dan Orang Tua dalam Kegiatan Belajar Dari Rumah Anak Usia Dini pada Masa Pandemi Covid-19. Jurnal Obsesi: Jurnal Pendidikan Anak Usia Dini, 5(2), 1454-1463. https://doi.org/10.31004/obsesi.v5i2.808

Christina, R. E., Mingkid, E., \& Londa, J. W. (2020). Peran komunikasi orang tua dalam mencegah kecanduan gadget pada anak usia dini di kelurahan karombasan utara. Acta Diurna Komunikasi, 2. https:// doi.org/10.36709/jspaud.v2i1.5922

Chusna, P. A. (2017). Pengaruh media gadget pada perkembangan karakter anak. Dinamika Penelitian: Media Komunikasi Sosial Keagamaan, 17(2), 315-330.

Faozi, K., Handayani, D., Supiyan, D., Hariansyah, O., \& Winarti, W. (n.d.). Sosialisasi aplikasi google family link sebagai parenting control tool pada anak di RA/TK rizqi pamulang. Jurnal Pengabdian Kepada Masyarakat, 1, 47-52.

Iftitah, S. L., \& Anawaty, M. F. (2020). Peran Orang Tua Dalam Mendampingi Anak Di Rumah Selama Pandemi Covid-19. JCE (Journal of Childhood Education), 4(2), 71. https://doi.org/10.30736/jce.v4i2.256

Karnawati, K., \& Mardiharto, M. (2020). Sekolah Minggu Masa Pandemi Covid 19: Kendala, Solusi, Proyeksi. Didache: Journal of Christian Education, 1(1), 13. https://doi.org/10.46445/djce.v1i1.291

Kemendikbud. (2020). Pedoman pelaksanaan belajar dari rumah selama darurat bencana cOVID-19 di indonesia. Sekretariat Nasional SPAB (Satuan Pendidikan Aman Bencana), 15

$1-16$.

https://www.kemdikbud.go.id/main/blog/2020/05/kemendikbud-terbitkanpedoman-penyelenggaraan-belajar-dari-rumah

Lase, B., \& Tafonao, T. (2021). Urgenitas pengawasan orang tua dalam mendampingi psikologi anak selama belajar daring di masa pandemi. 1(Juli), 15-27.

Maria, I., \& Novianti, R. (2020). The effects of using gadgets during the covid-19 pandemic on children's behaviour. Ațfāluna: Journal of Islamic Early Childhood Education, 3(2), 7481. https://doi.org/10.32505/atfaluna.v3i2.1966

Mubashiroh, M. (2013). Gadget, penggunaan dan dampak Pada anak-anak. Jurnal Ilmiah. http://jurnalilmiahtp2013.blogspot.com/2013/12/gadget-penggunaan-dan-dampakpada-anak.html

Muyasaroh, Ladamay, O. M. M. A., Mahfud, C., Mustakim, \& Sejati, Y. G. (2020). The utilization of gadget in maintaining prophetical values in millennial generation. International Journal of Psychosocial Rehabilitation, 24(4), 5602-5615. https://doi.org/10.37200/IJPR/V24I4/PR201655

Najwa, N. (2021). Pola asuh orangtua dalam mengantisipasi dampak penggunaan gadget di masa pandemi covid-19. Islamic Counseling: Jurnal Bimbingan Konseling Islam, 5(1), 79. https://doi.org/10.29240/ibk.v5i1.2466

Novitasari, N. (2019). Strategi pendampingan orang tua terhadap intensitas penggunaan gadget pada anak. Al-Hikmah: Indonesian Journal of Early Childhood Islamic Education, 3(2), 167-188. https:// doi.org/10.35896/ijecie.v3i2.77

Nurhidayah, I., Gilang Ramadhan, J., Amira, I., \& Lukman, M. (2019). Peran orangtua dalam pencegahan terhadap kejadian adiksi gadget pada anak: literatur review. Journal of Chemical Information and Modeling, 53(9), 1689-1699.

Nurjanah, Y. S., \& Irma, C. N. (2020). Peran Orang Tua Dalam Pendampingan Pembelajaran Daring AUD Pada Masa Pandemi Covid-19. 5(1), 91-98. https://doi.org/10.31004/obsesi.v5i1.630

Olifia, S., \& Nuraini, D. (2018). Komunikasi keluarga dalam mencegah dampak negatif penggunaan gadget. Komunikasi Keluarga Dalam Mencegah Dampak Negatif Penggunaan Gadget, 111-139. 
Prasanti, D. (2016). Perubahan media komunikasi dalam pola komunikasi keluarga di era digital. Jurnal Commed, 1(1), 2527-8673.

Putri, A. S. I. (2021). Kemampuan Guru PAUD dalam Mengelola pembelajaran pada masa pandemi covid-19. Jurnal Pendidikan Anak Usia Dini Undiksha, 9(1), 23. https:// doi.org/10.23887/paud.v9i2.35508

Roza, D., Nurhafizah, N., \& Yaswinda, Y. (2019). Urgensi profesionalisme guru pendidikan anak usia dini dalam penyelenggaraan perlindungan anak. Jurnal Obsesi : Jurnal Pendidikan Anak Usia Dini, 4(1), 277. https:// doi.org/10.31004/obsesi.v4i1.325

Roza, E., Kamayani, M., \& Gunawan, P. (2018). Pelatihan memantau penggunaan gadget pada anak. Jurnal SOLMA, 7(2), 208. https://doi.org/10.29405/solma.v7i2.1062

Saefulloh, A. (2018). Peran pendidik dalam penerapan internet sehat menurut islam. Al$\begin{array}{lllll}\text { Tadzkiyyah: Jurnal } & \text { Pendidikan } & \text { Islam, }\end{array}$ https://doi.org/10.24042/atjpi.v9i1.2709

Sisbintari, K. D., \& Setiawati, F. A. (2021). Digital parenting sebagai upaya mencegah kecanduan gadget pada anak usia dini saat pandemi covid-19. ... Obsesi: Jurnal $\begin{array}{lll}\text { Pendidikan Unak } & \text { 1562-1575. }\end{array}$ https:// doi.org/10.31004/obsesi.v6i3.1781

Tasya, M. R., \& Masitoh, S. (2020). Pendampingan orang tua kepada anak dalam mencegah dampak negatif dari gadget. ... Dakwah Dan Komunikasi, 2(5), 229-235. http://ejournal.uin-suska.ac.id/index.php/jrmdk/article/view/10556

Utama, F. P., Sari, J. P., \& Bismantolo, P. (2021). Peningkatan kapasitas orang tua dalam mengawasi aktivitas anak menggunakan gawai berbasis android dengan google family link. Abdi Reksa, 2(1), 9-15. https:/ / ejournal.unib.ac.id/index.php/abdireksa/article/view/13333

Utama, F., \& Hasti Hasmira, M. (2019). Bentuk pengawasan orang tua pada anak-anak pengguna smartphone. Culture \& Society: Journal Of Anthropological Research, 1(1), 103-109. https://doi.org/10.24036/culture/vol1-iss1/20

Wardani, A., \& Ayriza, Y. (2020). Analisis Kendala Orang Tua dalam Mendampingi Anak Belajar di Rumah Pada Masa Pandemi Covid-19. Jurnal Obsesi : Jurnal Pendidikan Anak Usia Dini, 5(1), 772. https://doi.org/10.31004/obsesi.v5i1.705

Warisyah, Y. (2015). "Pendampingan Dialogis" Orang Tua Dalam Penggunaan Gadget Pada Anak Usia Dini. Proseding Seminar Nasional Pendidikan, 2016(November 2015), 130138.

http://seminar.umpo.ac.id/index.php/semnasdik2015/article/download/212/213

Yannuansa, N., Kurniadi W, H., Mutrofin, A., Ramadhani, R., \& Samudra, A. (2020). Pengurangan pengaruh negatif gadget pada remaja dan anak melalui workshop. ABIDUMASY Jurnal Pengabdian Kepada Masyarakat, 1(1), 49-53. https://doi.org/10.33752/abidumasy.v1i1.656 